\title{
KAJIAN IMBALAN ATAS PNBP ROYALTI PATEN BAGI INVENTOR
}

\author{
Achmad Fauzan Sirat \\ Email: af.sirat05@gmail.com
}

\section{Intisari}

Imbalan atas PNBP Royalti Paten telah menjadi polemik selama bertahun-tahun pada inventor yang bernaung pada lembaga/institusi penelitian milik negara. Salah satu efek yang menjadi perhatian adalah hilangnya potensi temuan-temuan yang berefek pada perkembangan ekonomi dalam negeri karena para inventor lebih tertarik untuk "menjual" temuan dimaksud ke pihak luar dibawah tangan. Pemberian Imbalan merupakan pengembangan sistem pengakuan dan penghargaan di bidang $\mathrm{HKI}$, pemberian insentif akan berbanding lurus dengan pengembangan inovasi berbasis IPTEK yang bermanfaat secara ekonomi bagi bangsa yang pada akhirnya akan meningkatkan penerimaan negara bukan pajak.

Kajian ini menyimpulkan bahwa berdasarkan pertimbangan dimaksud maka imbalan perlu diposisikan sebagai kebijakan tarik ulur bergantung pada situasi dan kondisi yang berlaku. Memperhatikan segala risiko atas potensi kehilangan bagi negara yang lebih besar maka kebijakan pemberian imbalan merupakan kebijakan yang layak direkomendasikan.

Agar kebijakan ini dapat berjalan, perlu disiapkan 3 buah produk hukum seperti disebutkan dalam surat DJA Nomor S-1765/AG/2012 tanggal 09 Juli 2012, yakni: PP Tarif, KMK Persetujuan Penggunaan, dan PMK Standar Biaya mengenai Imbalan.

Kata kunci: royalti, PNBP, imbalan, standar biaya

\section{PENDAHULUAN}

\subsection{Latar Belakang}

Pemberian bagian dari royalti atas penggunaan HKI (Paten, Hak Cipta, dsb) kepada inventor yang membuat invensi telah menjadi polemik selama bertahuntahun pada inventor yang bernaung pada lembaga/institusi penelitian milik negara. Keinginan untuk memajukan temuantemuan inovatif yang menjadi salah satu aset bangsa guna meningkatkan daya saing teknologi dalam negeri dipandang terkendala insentif yang diperoleh inventor atas suatu temuan bernilai ekonomi yang dihasilkannya. Efek yang menjadi perhatian dari lembaga/instansi akan kondisi ini adalah hilangnya potensi temuan-temuan yang berefek pada perkembangan ekonomi dalam negeri karena para inventor lebih tertarik untuk "menjual" temuan dimaksud ke pihak luar dibawah tangan. Hal ini mengakibatkan posisi Indonesia sebagai negara tetap menjadi konsumen dari temuan dimaksud mengingat hak atas temuan tersebut tidak dimiliki oleh negara, atau setidaknya pihak di dalam negeri.

Berdasarkan hal tersebut tiga Kementerian/Lembaga, yakni: Menteri Ristek, BPPT, dan Menko Perekonomian bersurat kepada Menteri Keuangan sebagai upaya untuk mengajukan permohonan untuk menggunakan sebagian dari penghasilan yang didapat oleh lembaga dimaksud berupa royalti secara langsung kepada inventor [suratsurat tersebut antara lain Surat Sestama 
Badan Pengkajian dan Penerpan Teknologi Nomor B-214/SETAMA/HK06/09/2011 tanggal 14 September 2011 tentang Mekanisme dan Pemanfaat Royalty HKI Tersertifikasi, Surat Menristek nomor S101/M/XI/2013 tanggal 19 November 2013 tentang Usulan Pola Royalti HKI bagi Inventor, Surat Deputi Menko Perekonomian Bidang Koordinasi Perniagaan dan Kewirausahaan nomor S203/D.V.M.EKON/09/2013 tanggal 17 September 2013 tentang Royalty Fee atas Paten, Surat Kepala Badan Litbang Pekerjaan Umum nomor HK-0103-KL/101 tanggal 27 Januari 2014 tentang Usulan Satuan Biaya Masukan; serta Surat Asisten Deputi Persaingan Usaha dan Perlindungan Konsumen nomor S24/D.V.M.EKON.4/11/2013 tanggal 19 November 2013 tentang Pembahasan Mekanisme Penarikan Royalty Fee kepada Direktur PNBP dan Direktur Sistem Penganggaran].

Substansi yang dimaksud dalam surat yang melatarbelakangi kajian ini adalah bahwa perlu adanya pengaturan pemberian insentif yang memadai bagi inventor yang hasil invensinya menghasilkan PNBP bagi negara. Beberapa pertimbangan yang disampaikan antara lain untuk mendukung implementasi Masterplan Percepatan Pembangunan Ekonomi Indonesia (MP3EI) melalui kegiatan inovasi dibidang IPTEK berupa pengembangan sistem pengakuan dan penghargaan di bidang HKI, khususnya pengaturan sistem insentif berbasis royalti HKI bagi inventor berstatus pegawai negeri sipil. Perspektif yang dibangun dalam pengajuan ini adalah pemberian insentif akan berbanding lurus dengan pengembangan inovasi berbasis IPTEK yang bermanfaat secara ekonomi bagi bangsa. Dengan demikian pemberian insentif ini pada akhirnya, lebih spesifik, akan meningkatkan penerimaan negara bukan pajak dari sektor ini.

\subsection{Identifikasi Masalah}

Insentif yang didasarkan atas suatu invensi, khususnya untuk lembaga/instansi milik pemerintah, merupakan suatu pola baru pemberian insentif dalam kerangka penggunaan dana PNBP. Pola yang diajukan adalah memberikan insentif kepada seseorang berdasarkan nilai PNBP yang diperoleh dari hasil penggunaan suatu objek PNBP. Sampai dengan saat ini, pengaturan standar biaya hanya mengatur honorarium bagi pengelola PNBP (Atasan Langsung Bendahara, Bendahara, dan Anggota) didasarkan oleh pada pagu penerimaan instansi bersangkutan. Pengaturan yang ada merupakan pengaturan umum tanpa melihat objek PNBP yang menghasilkan mengingat pengelola PNBP yang disebutkan pada dasarnya adalah administrator atas penerimaan negara.

Dasar pemberian insentif yang diajukan berbeda dengan mekanisme PNBP pada umumnya. Insentif yang diajukan secara langsung mengacu pada objek yang menghasilkan PNBP, yaitu paten. Hal ini mengingat kontribusi subjek atas terbentuknya objek penghasil PNBP dimana hubungan subjek tersebut secara hukum diakui dalam suatu dokumen paten. Hal ini membuka perbedaan hubungan PNBP pada umumnya, dimana PNBP yang dihasilkan bukanlah atas dasar kewenangan instansi sebagai regulator atau operator dari suatu kebijakan. 
Walaupun pola PNBP royalti ini belum secara umum diatur, secara prinsip mekanisme yang dianut masih selaras dengan mekanisme penggunaan dana PNBP dimana sisi pengeluaran direalisasikan setelah ada transaksi pada sisi penerimaan. Dengan kata lain, sifat transaksi bersifat bruto bukan pengurangan langsung dari penerimaan sebelum disetorkan ke kas negara.

Akhirnya, jika kebijakan ini diambil, pertanyaan selanjutnya adalah bagaimana besaran imbalan akan ditentukan dan apa hal yang menjadi dasar dari besaran dimaksud. Selain itu patut dipertimbangkan apa sisi negatif sebagai penyeimbang dari sisi positif yang ada atas kebijakan ini.

\subsection{Tujuan}

Kajian ini berupaya mengulas lebih mendalam atas usulan Kementerian Ristek sebagai dimaksud. Hal ini sebagai dasar pertimbangan dalam melihat usulan pemberian insentif bagi inventor dari berbagai perspektif, antara lain: dasar hukum, mekanisme penganggaran, dan pertimbangan untuk penetapan imbalan.

\section{METODOLOGI PENELITIAN}

Kajian ini dibuat dengan menggunakan metode telaah literatur, antara lain: undang-undang terkait dan jurnal ilmiah terkait hak kekayaan intelektual. Selain itu, kajian ini membandingkan hasil kajian Kemen Ristek yang dilampirkan dalam usulan dengan jurnal umum yang ada.

\section{SISTEM HAK KEKAYAAN INTELEKTUAL}

\subsection{Sekilas Mengenai Penelitian dan Hak Kekayaan Intelektual}

Penelitian dan pengembangan
merupakan awal dari kemajuan dari
berbagai bidang, dimana kegiatan
penelitian dan pengembangan
memfasilitasi kemajuan dengan

mengurangi aksi "trial and error" secara massive. Layaknya bagi seseorang yang belajar berenang, penelitian dan pengembangan dilakukan untuk memformulasikan cara berenang yang efektif untuk pemula guna mengurangi risiko tenggelam bagi para perenang pemula. Terkait dengan hal tersebut penelitian dilakukan untuk menghasilkan pedoman untuk perenang pemula.

Pada sektor privat, pedoman untuk perenang pemula diperjualbelikan kepada masyarakat, dan masyarakat yang ingin memanfaatkannya akan membayar sejumlah tertentu. Hal ini dilakukan mengingat hasil penjualan pedoman tersebut merupakan sumber pendapatan bagi individu ekonomi (perusahaan). Selain itu, hasil pendapatan dari pedoman dimaksud diperuntukkan juga untuk mengembalikan biaya yang dikeluarkan selama proses pembuatan pedoman dimaksud termasuk biaya intelektual yang memformulasikan cara terbaik yang dituangkan dalam panduan berenang dimaksud. Selanjutnya, agar hak milik atas hasil penelitiannya dimaksud dilindungi, individu ekonomi (perusahaan) mengajukan paten atas temuannya itu. [Paten tersebut pada dasarnya merupakan hak milik atas ide yang dituangkan dalam pedoman dimaksud]. Secara keseluruhan yang dibayar oleh pembeli pedoman 
tersebut terdiri dari dua hal utama yakni cetakan pedoman dan ide yang terkandung dalam pedoman. Sebagai hasil akhir, pola win-win solution atas proses ini tercapai yaitu individu ekonomi mendapatkan insentif atas invensinya dan masyarakat perenang akan mendapatkan manfaat atas invensi orang lain dengan berkurangnya risiko kecelakaan bagi dirinya. Hal ini dapat kita catat sebagai skenario I atas pemanfaatan invensi.

Analogi diatas dapat memberikan gambaran bagaimana sistem hak kekayaan intelektual berlaku. Nampak dalam perumpamaan diatas bahwa yang diperjualbelikan adalah tidak semata-mata cetakan pedoman, namun terdapat ide yang dituangkan dalam pedoman tersebut juga menjadi unsur yang ditransfer ke pembeli. Oleh karena itu, pembeli pedoman tidak dapat menggandakan/memperbanyak buku yang menjadi miliknya untuk kemudian dijual kembali pada orang lain. Hal ini menunjukkan bahwa hak atas ide masih dimiliki pihak penemu ide bukan pihak yang memiliki produk. Sistem ini berupaya untuk memberikan insentif yang cukup agar inovasi-inovasi lainnya dapat tumbuh.

Pada sektor publik dimana kesejahteraan sosial menjadi tujuan, pemerintah perlu mencari cara agar kebutuhan seluruh komponen dari sebuah negara terpenuhi guna menghasilkan hasil yang optimum. Dalam hal negara berkepentingan untuk mengembangkan cabang renang sebagai contoh dan pemerintah mengetahui tingkat kemampuan masyarakatnya untuk membeli pedoman dimaksud, pemerintah dapat melakukan dua hal yakni mengakuisisi paten atas temuan diatas dan membagi kepada masyarakat untuk belajar renang, atau mengadakan sendiri penelitian untuk menghasilkan pedoman berenang yang lainnya (agar paten tidak dilanggar) dan membaginya kepada masyarakat. Sebut saja skenario akuisisi sebagai skenario II, dan skenario terakhir sebagai skenario III. Hal ini harus dilakukan mengingat pemerintah tidak dapat mencetak pedoman dimaksud tanpa adanya ijin penggunaan ide yang menjadi konten dari pedoman dimaksud.

Pertanyaan mendasar dalam hal skenario III digunakan adalah jika pemerintah menerapkan tarif atas temuan yang dihasilkan oleh institusinya atas dasar keadilan bagi semua warga sesuai dengan prinsip yang membayar adalah yang menerima manfaat (analogi yang sama saat pemerintah menerapkan tarif atas layanan tol), maka penggunaan dana hasil pembayaran dimaksud merupakan hak pemerintah. Konstruksi ini perlu mendapat penegasan untuk memperkuat kedudukan hak pemerintah diatas hak individu yang membentuk objek penghasilan. Dengan demikian, dalam hal pemerintah mengambil kebijakan untuk memberikan sebagian dari penghasilan perlu didudukkan bahwa aksi dimaksud bukan atas pembayaran hak individu, namun melainkan sebagai kerelaan pemerintah untuk menggunakan dana bagi individu tertentu guna mendapatkan manfaat yang lebih besar (misal: oportunity cost atas kehilangan pendapatan negara atau upaya untuk mempertahankan sumber daya strategis). 


\subsection{Komersialisasi Penelitian yang Dibiayai Sebagian dan atau Seluruhnya Oleh Pemerintah}

Penelitian yang dilakukan oleh pemerintah pada dasarnya merupakan praktik sebagaimana diuraikan dalam skenario III. Secara garis besar penelitian dilakukan guna menjadi katalis dalam mewujudkan kesejahteraan sosial, secara langsung maupun tidak. Salah satu contoh dari aplikasi atas penelitian ini dapat dilihat pada bidang pertanian berupa produksi bibit unggul tahan hama. Jika perusahaan pembuat bibit melakukan sendiri risetnya untuk menghasilkan produk tersebut maka bisa berimplikasi pada naiknya harga bibit yang akan dibeli oleh para petani atau bahkan berlaku monopoli atas bibit tertentu.

Pemerintah dalam hal ini pada dasarnya menyediakan barang publik demi memperoleh manfaat lebih besar bagi negara. Jika Pemerintah, dengan dana yang dipungut dari masyarakat, tidak membiayai penelitian dimaksud, maka ongkos penelitian akan ditanggung oleh produsen yang pada akhirnya akan dibebankan pada petani. Lebih buruk lagi, jika produsen tidak melakukan penelitian maka produksi petani akan sangat rentan turun akibat hama sehingga ongkos sosial yang akan ditanggung oleh pemerintah akan menjadi lebih besar. Sama halnya jika dari beberapa produsen bibit hanya ada satu produsen yang mampu melakukan penelitian dimaksud sehingga timbul monopoli atas temuan bibit dimaksud. Hal inilah yang melandasi bahwa pemerintah menyediakan barang publik dengan melakukan penelitian dimaksud sama halnya dengan jalan dan jembatan yang dibangun oleh pemerintah, khususnya untuk penelitian yang bersifat umum dan memiliki karakteristik barang publik (Wong, et.al, 2002).

Namun demikian, walaupun penelitian ini dimaksudkan untuk menyediakan barang publik pada umumnya tidak menutup kemungkinan adanya upaya komersialisasi hasil penelitian dimaksud. Hal ini didasari oleh pemikiran bahwa kebutuhan dana untuk melakukan penelitian dan pengembangan lebih lanjut adalah sangat besar dimana kemampuan negara untuk membiayai semua kegiatan juga terbatas. Sejalan dengan hal tersebut, dewasa ini penelitian yang dilakukan oleh pemerintah tidak terbatas pada sesuatu yang hanya dibutuhkan masyarakat pada umumnya, dimana penerima manfaatnya adalah pihak tertentu misalnya penelitian peleburan mineral. Berlandaskan pada prinsip keadilan dalam penerimaan manfaat oleh pemerintah dimana yang memperoleh pelayanan adalah pembayar dari layanan dimaksud, contoh pelayanan SIM dibayar oleh pengendara kendaraan bermotor bukan pejalan kaki, maka sebagian hasil penelitian dapat dikomersialkan untuk penerima manfaat tertentu.

Alasan lain dari komersialisasi adalah upaya mendorong para peneliti dan perekayasa untuk fokus pada kegiatan penelitian yang bermanfaat bagi industri, misalnya pemrosesan mineral langka. Potensi ekonomi yang tinggi atas riset tersebut telah membawa manfaat tidak hanya pada individu peneliti tapi juga negara secara keseluruhan. Dimana sejalan dengan perkembangan ekonomi dari penelitian dimaksud pada akhirnya akan 
membawa pada kesejahteraan sosial suatu negara.

Komersialisasi hasil penelitian oleh lembaga penelitian milik pemerintah telah dimulai di Amerika Serikat pada tahun 1980 saat kegiatan penelitian mengalami penurunan pasca Perang Dunia II (Edi dan Subiyanto, 2011). Kebijakan ini dikenal dengan kebijakan Bayh-Dole Act 1980 yang mempunyai tiga pokok tujuan, yakni: mendorong pemanfaatan hasil penelitian, mendorong pertautan antara kegiatan komersial dan kegiatan non-profit, dan meningkatkan komersialisasi dan aplikasi invensi bagi masyarakat. Sejak dikeluarkannya kebijakan tersebut jumlah paten yang dikeluarkan meningkat selama kurun waktu tahun 1982 sampai dengan tahun 2000 dari 500 menjadi 3.800 paten. Sejalan dengan hal tersebut, pendapatan hasil alih teknologi meningkat tujuh kali lipat dari \$186 juta menjadi \$1.26 juta pada universitas (Lach dan Schankerman, 2004).

Namun demikian komersialisasi secara umum tidak akan mendorong terciptanya paten lebih banyak tanpa didukung dengan kebijakan mikro mengenai penghargaan bagi inventornya. The Development Research Center of the State Council of the People's Republic of China (2003) menyebutkan bahwa selain memberikan keleluasaan untuk mengaplikasikan hasil penelitian oleh lembaga penelitian, peraturan yang berlaku di Amerika Serikat juga memberikan payung hukum untuk memberikan bagian dari hasil lisensi atas paten sebanyak $15 \%$ bagi inventor. Fakta tersebut menunjukkan bahwa ada insentif bagi para peneliti pemerintah untuk menghasilkan lebih banyak hasil penelitian yang dipatenkan atas nama negara mengingat adanya hubungan timbal balik atas kontribusinya dalam penelitian dimaksud. Selain itu, penelitian akan secara alaminya akan terarah pada kegiatan yang akan dapat diaplikasikan pada industri guna mendukung perekonomian.

Selain itu, secara tidak langsung kebijakan ini dapat mempertahankan talenta terbaik dalam menghasilkan temuan baru. Hal ini sejalan dengan kebijakan pemerintah diberbagai belahan dunia untuk mengupayakan menahan talenta terbaik untuk tidak ke luar negeri, atau yang lebih dikenal dengan istilah Brain Drain. Bahkan dalam tulisan yang dipublikasikan pada NBER Reporter, William Kerr (2013) menunjukkan bahwa daya saing Amerika Serikat dapat didukung dengan kebijakan yang sangat lunak untuk mempekerjakan innovator dari berbagai ethnis di dunia.

\subsection{Komersialisasi Penelitian dalam Konteks Indonesia}

Untuk kontek Indonesia, Kerangka hukum yang ada pada dasarnya sudah mempertimbangkan hal ini. Prinsip dasar yang dituangkan dalam UU 18 Tahun 2001 tentang Sistem Nasional Penelitian dan Pengembangan IPTEK, dan PP 20 Tahun 2005 tentang Alih Teknologi Kekayaan Intelektual serta hasil kegiatan penelitian dan pengembangan oleh Perguruan Tinggi dan Lembaga Penelitian dan Pengembangan mengatur akan hal yang sama. Pengaturan diatas menyebutkan tentang pelaksanaan penelitian, alih teknologi atas hasil penelitian, serta bagaimana pendapatan atas hasil penelitian digunakan kembali, termasuk 
tentang pemberian insentif yang diperlukan untuk meningkatkan motivasi dan kemampuan invensi di lingkungannya. Namun demikian secara eksplisit mengenai bentuk dan cara pemberian insentif dimaksud belum ada. Hal ini akan diulas lebih lanjut keterkaitan undang-undang yang terkait.

\section{DASAR HUKUM DAN MEKANISME}

\subsection{Telaah Dasar Hukum atas Penelitian yang Dibiayai oleh Pemerintah}

Dasar Hukum yang menjadi pertimbangan dalam kajian ini antara lain sebagai berikut:

- UU 20 Tahun 1997 tentang Penerimaan Negara Bukan Pajak;

- UU 14 Tahun 2001 tentang Paten, pasal 12 ayat ( 3 );

- UU 18 Tahun 2002 tentang Sistem Nasional Penelitian dan Pengembangan IPTEK;

- UU 19 Tahun 2002 tentang Hak Cipta;

- UU 17 Tahun 2003 tentang Keuangan Negara;

- UU 1 Tahun 2004 tentang Perbendaharaan Negara;

- UU 29 Tahun 2009 tentang Perlindungan Varietas Tanaman;

- PP 73 Tahun 1999 tentang Tata Cara Penggunaan PNBP;

- PP 20 Tahun 2005 tentang Alih Teknologi Kekayaan Intelektual serta hasil kegiatan penelitian dan pengembangan oleh Perguruan Tinggi dan Lembaga Penelitian dan Pengembangan;

- PP 23 Tahun 2005 tentang Pengelolaan Keuangan Badan Layanan Umum;

- PP 90 Tahun 2010 tentang Penyusunan Rencana Kerja dan Anggaran Kementerian Negara/Lembaga;
Pengaturan mengenai penggunaan kembali PNBP diatur oleh PP 73 Tahun 1999 tentang Tata Cara Penggunaan PNBP sebagai turunan dari UU 20 Tahun 1997 tentang PNBP. Pasal 4 (1) PP 73 Tahun 1999 menyatakan bahwa sebagian dana dari suatu PNBP dapat digunakan dimana disebutkan dalam pasal 4(2) bahwa besaran bagian dana ditetapkan oleh Menteri Keuangan. Selanjutnya dalam pasal 8 (1) disebutkan bahwa penggunaan dana PNBP dapat digunakan dalam rangka pembiayaan: a. operasional dana pemeliharaan, dan atau; b. investasi, termasuk peningkatan kualitas sumber daya manusia. Selain itu, dalam penjelasan pasal 6 (2) huruf a disebutkan salah satu contoh tujuan penggunaan PNBP antara lain adalah untuk meningkatkan produktivitas kerja.

Konstruksi pengaturan diatas pada dasarnya tidak secara eksplisit menjelaskan tentang penggunaan PNBP dimaksud diluar pembiayaan operasional dana pemeliharaan dan atau investasi. Namun demikian interpretasi lebih lanjut dari suatu kegiatan investasi perlu disamakan dengan usaha untuk mengembangkan diri, seperti usaha jasa sewa mobil akan mengembangkan diri dengan melakukan investasi pengadaan mobil tambahan. Investasi bagi ekonom diartikan sebagai kegiatan produksi untuk menghasilkan produksi yang lain. Oleh karena itu konsekuensi dari sebuah investasi adalah ekspektasi atas manfaat dimasa mendatang. Investasi sendiri dapat berupa investasi fisik dan non fisik dimana contoh investasi non fisik adalah investasi atas human capital.

Penggunaan kembali PNBP hasil dari pemanfaatan invensi (istilah yang 
digunakan: alih teknologi) sendiri telah diatur dalam berbagai peraturan perundang-undangan sektoral, seperti UU Nomor 18 tahun 2002 tentang Sistem Nasional Penelitian dan pengambangan Ilmu Pengetahuan dan Teknologi, dan PP nomor 20 tahun 2005 tentang Alih Teknologi Kekayaan Intelektual serta Hasil Kegiatan Penelitian dan Pengembangan oleh Perguruan Tinggi dan Lembaga Penelitian dan Pengembangan.

UU nomor 18 tahun 2002 pasal 16 (3) menyebutkan bahwa "Perguruan Tinggi dan Lembaga Litbang Pemerintah berhak menggunakan pendapatan yang diperolehnya dari hasil alih teknologi dan/atau pelayanan jasa ilmu pengetahuan dan teknologi untuk mengembangkan diri". Hal ini memiliki arti bahwa hasil pemanfaatan dari invensi yang dimiliki lembaga dimaksud dapat digunakan kembali guna pengembangan (riset) lebih lanjut.

Adapun penggunaan pendapatan dimaksud dijelaskan lebih lanjut dalam PP Nomor 20 tahun 2005, pasal 38 ayat (2), yakni:

a. meningkatkan anggaran penelitian dan pengembangan yang diperlukan untuk menguasai kemajuan iptek dan pengembangan sains;

b. memberikan insentif yang diperlukan untuk meningkatkan motivasi dan kemampuan invensi di lingkungannya;

c. memperkuat kemampuan pengelolaan dan alih teknologi kekayaan intelektual serta hasil kegiatan penelitian dan pengembangan;

d. melakukan investasi untuk memperkuat sumber daya iptek yang dimiliki; e. meningkatkan kualitas dan memperluas jangkauan alih teknologi kekayaan inteletual serta hasil kegiatan penelitian dan pengembangan dan pelayaan jasa ilmu pengetahuan dan teknologi, dan

f. memperluas jaringan kerja dengan lembaga-lembaga lan yang berkaitan dengan pelaksanaan tugas dan tanggung jawabnya, baik di dalam maupun luar wilayah NKRI.

Memperhatikan hal tersebut diatas, hasil dari pemanfaatan invensi menurut peraturan perundangan dapat digunakan kembali oleh institusi penghasil guna pengembangan dalam arti yang luas. Dimana secara sederhana dapat dikatakan bahwa PP Nomor 20 tahun 2005 memberikan penjelasan atas penggunaan pendapatan hasil pemanfaatan invensi ditujukan untuk membuat invensi baru, mengelola invensi yang ada beserta pemberdayaannya, dan memelihara invensi serta pengembangannya. Hal ini memberikan gambaran menyeluruh atas pengeluaran apa yang dibutuhkan agar suatu institusi secara berkelanjutan akan menghasilkan invensi-invensi baru.

Dengan demikian makna investasi non fisik pada Human Capital pun perlu ditarik dalam interpretasi lebih luas sebagaimana tercantum dalam PP Nomor 20 tahun 2005, pasal 38 ayat (2) huruf b, yakni memberikan insentif yang diperlukan guna mendapatkan manfaat yang lebih besar dimasa yang akan datang. Namun demikian perlu diingat bahwa insentif dimaksud dilandaskan bukan semata-mata karena hak individu seseorang atas penerimaan negara tapi harus dikonstruksikan sebagai upaya pemerintah untuk mendapatkan manfaat yang lebih 
besar dan meminimalkan risiko adanya oportunity cost atas kehilangan pendapatan negara atau upaya untuk mempertahankan sumber daya strategis (brain gain).

\subsection{Bentuk Imbalan}

Usulan Menteri Ristek, BPPT, dan Menko Perekonomian memperkecil fokus pada insentif yang diterima oleh inventor mengingat kunci dari penciptaan suatu invensi adalah inventornya. $\mathrm{K} / \mathrm{L}$ dimaksud mendasarkan tuntutannya pada pasal 12 ayat 3 UU 14 Tahun 2001 tentang Paten, dimana disebutkan bahwa inventor sebagaimana pada ayat (1) dan ayat (2) berhak mendapatkan imbalan yang layak dengan memperhatikan manfaat ekonomi yang diperoleh dari invensi dimaksud. hal tersebut yang mendasari pengusulan menggunakan sebagai dari fee atas royalti invensi dipergunakan untuk memberikan insentif bagi inventor. Adapun bentuk insentif yang diusulkan berupa sebagaimana yang tercantum dalam ayat

(4) pasal berkenaan, yaitu:

a. jumlah tertentu dan sekaligus

b. prosentase; c. gabungan antara (1) dan (2);

d. gabungan antara presentase dan hadiah atau bonus, atau;

e. bentuk lain yang disepakati para pihak;

f. yang besarnya ditetapkan oleh pihakpihak yang bersangkutan.

(dalam UU 14 Tahun 2001 tentang Paten insentif ini disebut dengan kata Imbalan)

Berdasarkan UU dimaksud, sejatinya usulan insentif yang dimintakan adalah berupa bagian dari pembayaran royalti yang dibayarkan berbentuk prosentase tertentu atau poin (b). Kajian dari Kemenristek menyebutkan bahwa hal ini dimaksudkan sebagai bentuk keadilan dan motivasi yang lebih bagi para inventor untuk berkarya dalam kerangka yang lebih luas. UU lain yang terpengaruh dalam kebijakan ini adalah UU 29 Tahun 2000 tentang Perlindungan Varietas Tanaman. UU ini pada dasarnya merupakan kebijakan "paten" untuk tumbuhan. Imbalan sebagaimana dimaksud diatas juga disebutkan dalam pasal 8 Undang-undang ini. Pada dasarnya dari keenam bentuk diatas dapat disarikan kedalam dua bentuk utama untuk dinilai pro kontranya sebagai berikut disajikan dalam tabel 1 .

Tabel 1. Perbandingan Dua Jenis Imbalan

\begin{tabular}{|c|c|c|}
\hline Nama & Pro & Kontra \\
\hline $\begin{array}{l}\text { Jumlah tertentu } \\
\text { dan Sekaligus }\end{array}$ & $\begin{array}{l}\text { - } \quad \text { bersifat global } \\
\text { - } \quad \text { adanya pemberlakuan yang } \\
\text { sama utk setiap inventor di } \\
\text { K/L berbeda }\end{array}$ & $\begin{array}{l}\text { - } \quad \text { tidak berkeadilan } \\
\text { - } \quad \text { kompleksitas penentuan } \\
\text { besaran imbalan }\end{array}$ \\
\hline Prosentase & $\begin{array}{ll}\text { - } & \text { lebih berkeadilan } \\
\text { - } & \text { lebih mudah dalam } \\
\text { penentuan besaran imbalan }\end{array}$ & $\begin{array}{ll}\text { - } & \text { bersifat lokal } \\
\text { - } & \text { memungkinkan adanya } \\
\text { perbedaan besaran utk setiap } \\
\text { inventor di K/L berbeda }\end{array}$ \\
\hline
\end{tabular}

Dalam kedua undang-undang dimaksud, insentif untuk para inventor disampaikan dalam istilah imbalan. Istilah ini sangat sesuai dengan konstruksi hukum 
yang dipakai dalam kajian ini yakni tidak menganggap insentif sebagai bagian dari hak individu inventor atas invensi yang menghasilkan PNBP, melainkan merupakan bentuk kerelaan pemerintah untuk menggunakan sebagian penghasilannya untuk manfaat yang lebih besar.

\subsection{Mekanisme Imbalan}

Berkenaan dengan mekanisme, pengaturan diatas perlu diselaraskan pengaturan sebagaimana tercantum dalam UU 20 Tahun 1997 tentang PNBP serta PP 73 Tahun 1999 tentang Tata Cara Penggunaan PNBP. Oleh karena itu, PP Nomor 20 tahun 2005, pasal 38 ayat (2) sepanjang tidak diartikan sebagai penggunaan secara langsung atas hasil Penerimaan Negara Bukan Pajak yang dihasilkan maka kedua aturan itu tidak ada yang bertentangan. Atau dengan kata lain, penggunaan kembali atas PNBP dimaksud harus menggunakan mekanisme bruto yang dikenal dalam pengelolaan PNBP.

Secara mendasar, DJA telah memberikan solusi atas permohonan dengan substansi sejenis dalam surat DJA Nomor S1765/AG/2012 tanggal 09 Juli 2012 dengan mempersiapkan tiga paket peraturan yang perlu dipersiapkan terkait dengan usulan dimaksud, yakni:

a. PP tentang Jenis dan Tarif atas PNBP;

b. KMK tentang persetujuan penggunaan sebagian dana PNBP pada K/L yang memasukkan penggunaan PNBP Royalti;

c. PMK Standar Biaya terkait dengan besaran imbalan.

Peraturan Pemerintah tentang Jenis dan Tarif merupakan dasar bagi kementerian/lembaga untuk memungut PNBP Royalti atas hasil lisensi atas paten. Keputusan Menteri Keuangan tentang persetujuan penggunaan merupakan bagian dari keputusan Menteri mengenai persentase penggunaan yang dijinkan dan peruntukan penggunaan secara umum. Selanjutnya PMK Standar Biaya merupakan pengaturan mengenai komponen apa yang dapat dikeluarkan, terutama untuk sesuatu yang menambah penghasilan dan fasilitas.

Skema pada gambar 1 mencoba menggambarkan bagaimana mekanisme dihubungkan dengan peraturan yang perlu disiapkan agar pemberian imbalan dapat mengakomodasi kerangka peraturan perundang-undangan yang berlaku.

Gambar 1 Skema Pemberian Imbalan atas PNBP Royalti

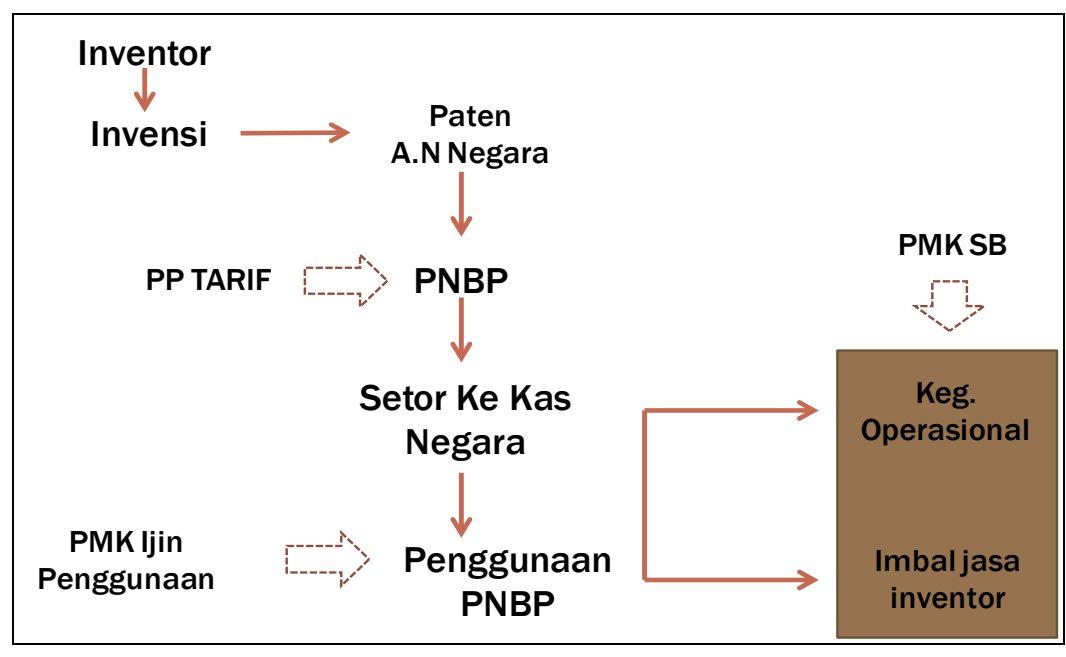


Namun demikian terdapat satu usulan yang tidak dapat diselesaikan hanya dengan ketiga paket peraturan diatas, yakni pemberlakukan imbalan/insentif tanpa batas waktu. dengan kata lain, apakah inventor tersebut masih aktif sebagai pegawai maupun tidak, imbalan tetap diberikan sepanjang masa paten masih berlaku dan menghasilkan manfaat ekonomis berupa royalti. Hal ini tidak dimungkinkan karena peraturan SBM secara umum terkait dengan pegawai (baik PNS maupun non PNS) yang aktif.

\section{PERTIMBANGAN TEKNIKAL ATAS IMBALAN}

\subsection{Pertimbangan Perhitungan Biaya}

Bagian ini mencoba mengemukakan beberapa hal yang perlu diperhatikan dalam memperhitungkan berapa porsi dari suatu invensi yang dapat diberikan bagi inventor. Memperhatikan pasal 38 ayat (2) PP 20 Tahun 2005, komponen biaya dalam menghasilkan suatu invensi berupa: komponen biaya pembentuk invensi itu sendiri, komponen biaya pengelolaan invensi, dan komponen biaya pemeliharaan invensi.

Komponen biaya pembentuk invensi berupa biaya yang dikeluarkan sampai dengan invensi terwujud termasuk pengembangannya, seperti peralatan, bahan, catatan, tenaga kerja dlsb. Selanjutnya, komponen biaya pengelolaan invensi merupakan biaya yang dikeluarkan saat suatu objek sudah berwujud dan bisa dimanfaatkan, seperti biaya pemasaran, biaya kontrak dlsb. Sedangkan, komponen biaya pemeliharaan berupa biaya-biaya yang dikeluarkan agar manfaat ekonomis masih dalam kekuasaan pemegang hak cipta, seperti biaya litigasi, dan biaya paten. Dengan demikian, biaya yang dikeluarkan sampai dengan suatu invensi dapat dimanfaatkan merupakan penjumlahan dari biaya yang dikeluarkan untuk membuat sampai dengan biaya pemeliharaan invensi dimaksud.

Pada awal penelitian, pada umumnya biaya yang dikeluarkan adalah biaya proposal riset bahwa penelitian ini layak mendapatkan pendanaan sehingga biaya yang dibutuhkan belum signifikan. Selanjutnya seiring dengan perkembangan biaya akan bertambah saat manfaat dari teknologi sudah lebih nyata. Biasanya pada fase lanjutan teknologi hasil temuan akan dicoba dalam skala yang lebih besar untuk melihat kelayakannya dalam produksi massal. Fase ini akan membutuhkan dana yang sangat besar sampai dengan teknologi benar-benar dapat diaplikasi secara umum. Gambar 2 mengilustrasikan besaran biaya yang dikeluarkan sepanjang waktu sampai dengan suatu Paten dihasilkan berdasarkan waktu pengeluaran.

Biaya-biaya terkait dengan pelaksanaan riset maupun pengembangan ini pada dasarnya telah dibiayai oleh negara sebagai bentuk investasinya dalam bidang iptek, mulai dari usulan pendanaan riset sampai dengan biaya pemeliharaan, baik untuk riset yang berhasil menghasilkan sebuah invensi maupun yang tidak. lebih khusus pada individu yang menggerakkan riset dan pengembangan negara telah memberikan penambahan take home pay berupa tunjangan fungsional peneliti. Selain itu, biaya pendaftaran paten untuk invensi termasuk biaya pemeliharaan tahunan juga ditagihkan pada negara. Sejalan dengan itu 
biaya litigasi jika terdapat suatu dispute atas invensi dimaksud selayaknya juga merupakan biaya bagi negara sebagai pemilik.

\section{Gambar 2 Simulasi Biaya Penelitian}

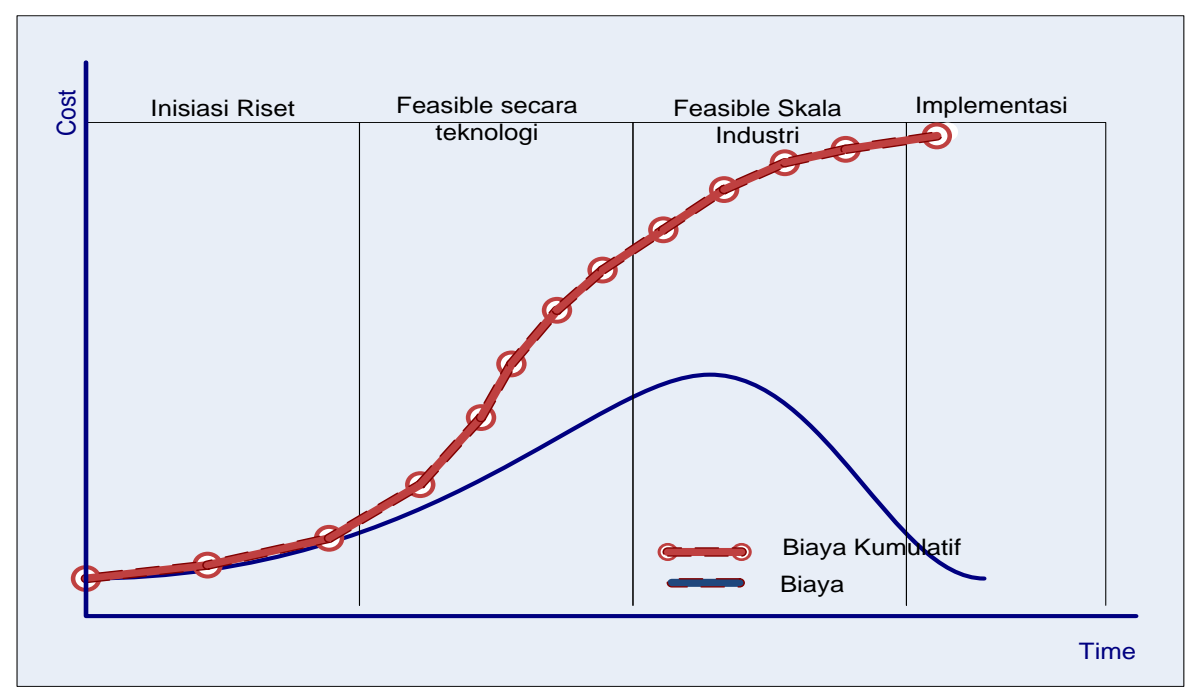

Berkenaan dengan hal tersebut, secara perhitungan bisnis adalah suatu yang lumrah jika pendapatan yang diperoleh perlu ditandingkan dengan biaya yang dikeluarkan untuk mendapatkannya sehingga setiap penambahan biaya yang diusulkan juga harus memperhatikan potensi pendapatan yang dihasilkan. Usulan pemberian sebagian pendapatan dari hasil pemanfaatan sebuah invensi seharusnya menggunakan kerangka pikir yang sama dalam menentukan besarannya mengingat pemberian sebagian pendapatan merupakan tambahan biaya bagi institusi penyelenggara riset.

Mengingat variasi penelitian yang dikeluarkan oleh institusi masing-masing dalam menghasilkan Paten maka pemberian imbalan dari suatu institusi dengan institusi yang lain dapat berbeda sesuai dengan berapa yang digunakan untuk membentuknya paten dimaksud. Hal inilah yang tercermin dari ijin penggunaan yang tercantum dalam suatu KMK ijin penggunaan.

Oleh karena itu, usulan yang disampaikan dalam surat dimaksud adalah $40 \%$ dari penerimaan royalti, selayaknya usulan tidak hanya didasarkan atas kajian atas kelayakan bagi penerima namun juga memperhatikan segala biaya yang dikeluarkan sampai suatu invensi dapat dimanfaatkan. Selain itu, segala proses litigasi yang muncul setelah Paten diberikan merupakan proses yang perlu dibiayai oleh institusi (bukan perseorangan) dalam memelihara invensi dimaksud walaupun inventor secara pribadi bertanggungjawab atas keabsahan temuannya.

Hal ini menjadi dasar untuk memastikan adanya dua hal penting yang perlu diakomodasi dalam kebijakan, yakni:

a. Mempertimbangkan biaya atas invensi dalam pemberian imbalan (hal yang direpresentasikan oleh ijin penggunaan dengan KMK) 
b. Mereduksi nilai usulan tanpa menimbulkan konflik dengan stakeholder (hal ini bisa direpresentasikan dengan menggunakan besaran secara progresif/regresif)

\subsection{Besaran Imbalan}

Usulan besaran yang diajukan dalam kajian Kementerian Riset dan Teknologi adalah $40 \%$ dari nilai PNBP Royalti. Tabel berupa perbandingan besaran royalti inventor di berbagai negara/institusi dalam negeri disajikan dalam kajian sebagaimana tercantum pada tabel 2.

Tabel 2 Perbandingan Besaran Royalti Inventor di Berbagai Negara/Institusi

\begin{tabular}{|l|l|l|}
\hline \multicolumn{1}{|c|}{ Institusi/Negara } & Besaran Royalti Bagi Inventor & \multicolumn{1}{c|}{ Keterangan } \\
\hline Riken (Jepang) & $50 \%$ & Diimplementasikan \\
\hline TIT (Jepang) & $30 \%$ & Diimplementasikan \\
\hline Boeing (USA) & $10 \%$ & Diimplementasikan \\
\hline BMI (USA) & $10 \%$ & Diimplementasikan \\
\hline Malaysia & $60 \%$ & Diimplementasikan \\
\hline BPPT (Indonesia) & $40 \%$ & Tidak Dapat Diimplementasikan \\
\hline ITB (Indonesia) & Sepertiga & Tidak Dapat Diimplementasikan \\
\hline BATAN (Indonesia) & $60 \%$ & Tidak Dapat Diimplementasikan \\
\hline LIPI & $\begin{array}{l}\text { (n) (nilai 200jt), 30\% (nilai } \\
\text { 200jt-500jt, 20\% (diatas 500jt) }\end{array}$ & Tidak Dapat Diimplementasikan \\
\hline Kementerian Pertanian & $40 \%$ & Tidak Dapat Diimplementasikan \\
\hline Kementerian PU & $45 \%$ & Tidak Dapat Diimplementasikan \\
\hline
\end{tabular}

Sumber: Asdep KL dan Standardisasii Iptek-Kemenristek 2013

Kajian Kementerian Riset dan Teknologi menyatakan bahwa pemberian $40 \%$ bagian dimaksud adalah berdasarkan pertimbangan adanya trend pemberian bagian dari royalti dimaksud yang berkisar antara $10 \%$ sampai dengan $60 \%$ pada sektor privat maupun lembaga pemerintah dan perguruan tinggi.

Sebagaimana disebutkan dalam sub bagian sebelumnya, besaran atas imbalan seharusnya tidak memperhatikan semata-mata kelayakan jumlah nominal namun juga perlu mempertimbangkan biaya yang digunakan terkait dengan pembentukan, pengelolaan dan pemeliharaan suatu invensi. Oleh karena itu, imbalan perlu diformulasikan dengan mempertimbangkan KMK Persetujuan Penggunaan sebagai bagian dari proxy atas biaya yang dikeluarkan pemerintah dalam proses kejadian objek paten. Dengan kata lain, prosentase besaran tidak bisa dikaitkan secara langsung dengan jumlah PNBP namun terlebih dahulu diseimbangkan dengan mengalikan jumlah prosentase persetujaun penggunaan dana sebagaimana tercantum dalam KMK Persetujuan Penggunaan.

Berkenaan dengan besarannya, angka $40 \%$ dirasa terlalu besar untuk sebuah kebijakan awal. Konsekuensi dari hal ini adalah adanya kemungkinan 
kebijakan ini akan menjadi batu loncatan bagi kebijakan yang lebih ekstrem seperti menaikkan angka usulan menjadi lebih besar dari usulan existing. Hal ini perlu diantisipasi agar tujuan utama peningkatan PNBP dari sektor non SDA tetap bisa tercapai tanpa mengurangi kapasitas fiskal negara yang disebabkan oleh bertambahnya nilai imbalan kepada inventor. Namun demikian perlu dilakukan upaya untuk mereduksi nilai usulan tanpa menimbulkan konflik dengan stakeholder misalnya dengan menggunakan besaran secara progresif/regresif sesuai dengan jumlah PNBPnya. Hal ini akan menurunkan angka prosentase efektif menjadi kurang dari $40 \%$ pada jumlah tertentu.
PP

$=$

KMK

tentang Persetujuan Penggunaan PNBP

I = Imbalan;

Tarif Progresif = daftar tarif

Dengan Simulasi penghitungan imbalan secara progresif dengan DPI sebesar Rp. 1.000.000.000,- adalah sebagai berikut:

\subsection{Siapa Yang Memperoleh Bagian Dari Royalti}

Sebagaimana disebutkan dalam usulan bahwa bagian dari royalti diberikan kepada inventor yang menghasilkan invensinya guna memotivasi untuk berkarya lebih sebagaimana disebutkan dalam dasar hukum yang mendasari usulan

\begin{tabular}{|l|l|l|l|l|}
\hline \multicolumn{2}{|c|}{ Tarif Progresif } & \multicolumn{1}{c|}{ Penghitungan Progresif } & \multicolumn{1}{c|}{ Nilai DPI } & \multicolumn{1}{c|}{ Penghitungan } \\
\hline \hline $\begin{array}{l}\text { sampai dengan Rp.100 } \\
\text { Juta }\end{array}$ & $40 \%$ & Rp.100 juta-Rp.0,- & Rp.100.000.000,- & Rp. 40.000.000,- \\
\hline $\begin{array}{l}\text { lebih dari Rp 100 juta } \\
\text { sampai dengan Rp 500 } \\
\text { juta }\end{array}$ & $30 \%$ & Rp.500 juta - Rp.100 juta & Rp.400.000.000,- & Rp.120.000.000,- \\
\hline $\begin{array}{l}\text { lebih dari Rp 500 juta } \\
\text { sampai dengan Rp 1 } \\
\text { milyar }\end{array}$ & $20 \%$ & Rp.1 Milyar- Rp.500 juta & Rp.500.000.000,- & Rp.100.000.000,- \\
\hline \begin{tabular}{l} 
lebih dari Rp 1 milyar \\
\hline Total
\end{tabular} & $10 \%$ & Rp.1 Milyar- Rp.1 Milyar & Rp. 0,- & Rp.0,- \\
\hline \hline
\end{tabular}

Untuk itu, besaran yang diusulkan untuk penghitungan imbalan dalam kajian ini adalah sebagai berikut:

- Penghitungan dasar imbalan menggunakan formula sebagai berikut: DPI = PNBP Royalti $\times$ PP

- Besaran imbalan dihitung dengan formula sebagai berikut:

I = DPI x Tarif Progresif

Keterangan:

DPI = Dasar

Penghitungan Imbalan;

PNBP Royalti = Nilai PNBP Royalti setahun; dimaksud. Pertanyaan selanjutnya adalah siapakah inventor yang dimaksud? inventor yang dimaksud adalah orang atau beberapa orang yang secara sendiri atau bersama-sama menghasilkan invensi. Inventor bisa hanya seorang dalam beberapa kasus terjadi dalam beberapa temuan seperti penelitian mikrobiologi, atau beberapa orang dalam suatu tim kerja seperti penelitian robotik. Lebih lanjut, status kepegawaian inventor bersangkutan dalam praktiknya dapat sebagai PNS atau Non PNS, bahkan kerjasama dengan pihak ketiga, misalnya seorang visiting professor. Dengan ini maka pertanyaan selanjutnya adalah siapa yang berhak atas bagian dari 
royalti dimaksud? jawaban ini merupakan

penentu dari apakah royalti bisa

"diwariskan" atau tidak.

\section{Gambar 3. Pembentukan Paten dengan Berbagai Unsur}

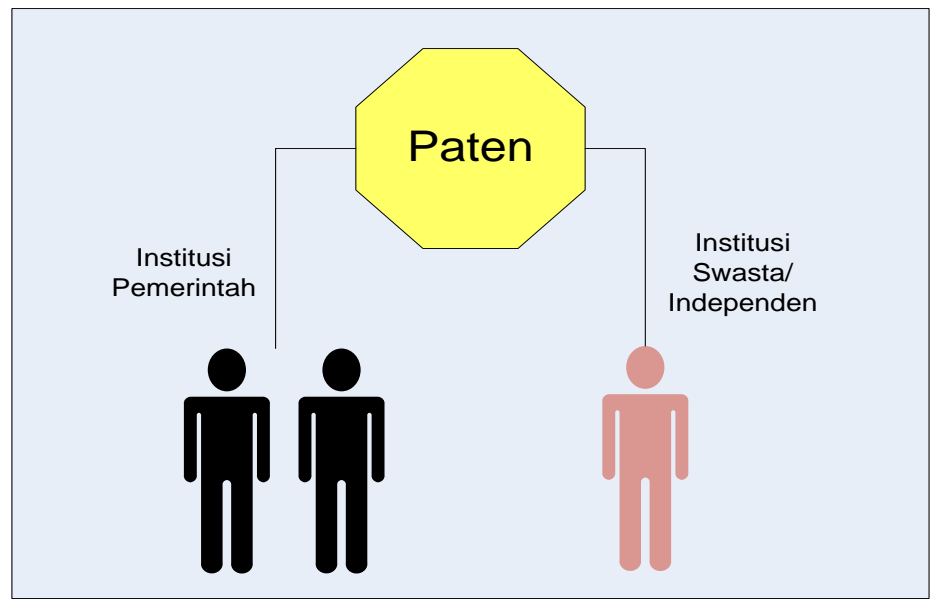

Sebagaimana ditunjukkan pada gambar 3, paten dapat dapat melibatkan banyak pihak. Ada setidaknya tiga kemungkinan unsur peneliti dalam sebuah paten. Kemungkinan pertama adalah semua peneliti adalah Pegawai Negeri Sipil dari institusi pemegang paten (tanpa memperhatikan apakah PNS dimaksud merupakan fungsional peneliti atau tidak). Kemungkinan kedua adalah semua pegawai dari sebuah institusi pemegang paten dimana sebagian PNS dan sebagian lain Non PNS. Kemungkinan terakhir adalah peneliti tergabung dalam joint research dengan mengikutsertakan pihak/institusi luar pemerintah.

Dalam hal ini, insentif atas bagian dari royalti adalah relevan hanya untuk pegawai institusi yang berkontribusi atas

\footnotetext{
${ }^{6}$ Joint Research adalah penelitian yang dilakukan oleh dua institusi atau satu institusi dengan pihak expert dari lembaga lain atas objek yang sama. Sebagai contoh proyek NAMRU dengan Kementerian Kesehatan. Kepemilikan atas Paten yang dihasilkan kegiatan ini biasanya tercantum dalam kontrak/nota kesepahaman penelitian. Dalam hal lembaga pemerintah melakukan hal
}

paten milik institusi dimaksud. Hal ini berarti bagian yang diperhitungkan adalah bagian porsi bersih untuk institusi penghasil paten, dalam hal penelitian merupakan joint research dengan pihak lain ${ }^{6}$. Kerangka pikir ini diilustrasikan pada gambar 4, dimana garis A, B, dan C merupakan hubungan kepemilikan atas objek paten. Dengan demikian, aliran penerimaan royalti atas paten juga direpresentasikan oleh garis-garis tersebut mengingat subjek diujung garis dimaksud merupakan pemilik dari objek paten. Selanjutnya garis D dan E merupakan alur pemberian imbalan sebagaimana diatur dalam UU 14 Tahun 2001. Dengan kerangka berpikir yang sama, bagian atas royalti dimaksud dalam pengaturan Standar Biaya tidak lagi memperhitungkan

semacam ini, pengaturan standar biaya tidak melakukan pengaturan atas porsi untuk pihak diluar lembaga pemerintah. Namun pengaturan hanya berlaku pada porsi bersih milik pemerintah. Dengan demikian pengaturan imbalan hanya relevan untuk kontributor internal atas paten dan tidak mengatur imbalan yang diberikan institusi mitra kepada inventornya. 
bagian imbalan untuk peneliti/inventor lain (bukan pegawai yang pekerjakan oleh institusi ini)

Gambar 4 Kepemilikan Paten, Aliran Penerimaan, dan Imbalan

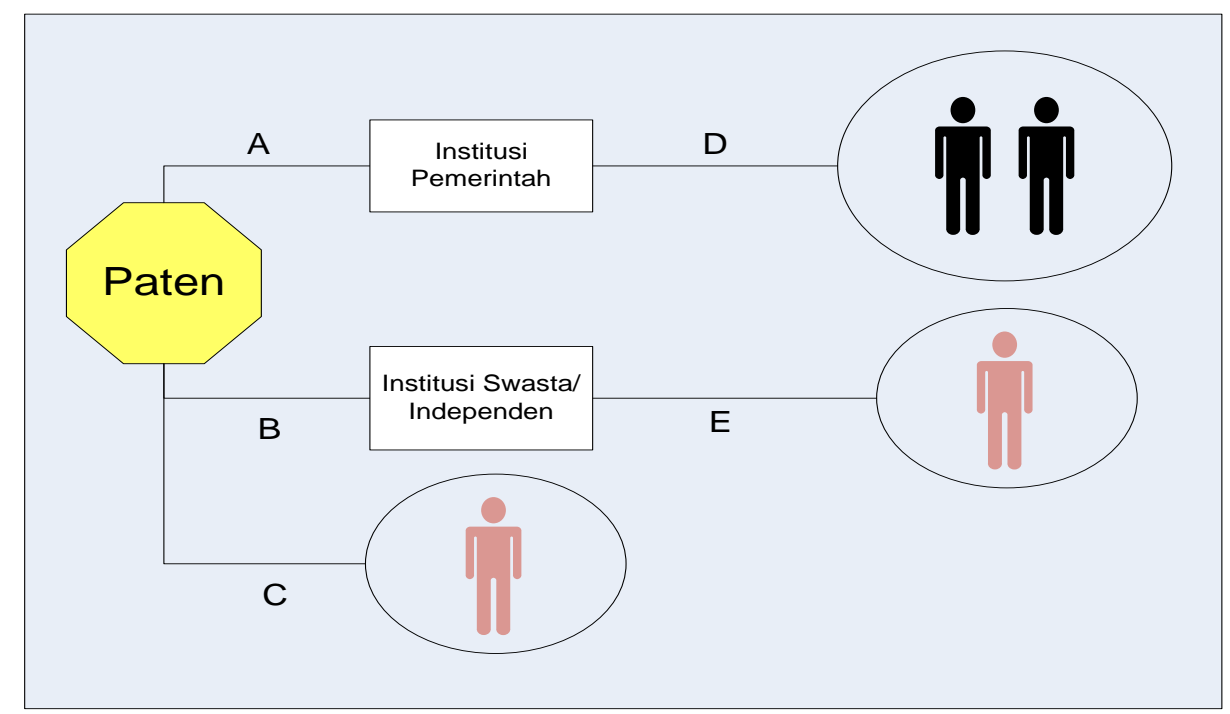

Selanjutnya, apakah inventor yang dimaksud adalah PNS atau juga non-PNS? Ketentuan sistem paten pada peraturan yang berlaku sebenarnya tidak mengakomodasi perbedaan antara status kepegawaian tersebut. UU 14 Tahun 2001 hanya menyebutkan bahwa inventor berhak mendapatkan imbalan yang layak dengan mempertimbangkan manfaat ekonomi dari invensinya, dalam hal ini inventor yang tercatat dalam dokumen paten. Dengan demikian kerangka tunjangan fungsional peneliti yang telah ditetapkan dengan Perpres 100/2012 menjadi tidak relevan, tidak hanya pada inventor yang tidak berstatus PNS, namun juga bagi inventor yang bukan peneliti.

Diskusi lebih lanjut adalah sampai kapan manfaat akan diberikan kepada penerima manfaat. Jika bagian dari royalti dimaksud hanya diperuntukkan bagi inventor dengan status PNS, maka royalti dimaksud hanya diberikan pada saat PNS tersebut aktif sebagai PNS. Hal ini mengingat setiap upah atas kontribusi PNS diberikan pada saat PNS dimaksud aktif. Namun apabila bagian dari royalti ditujukan kepada semua yang tergabung dalam pembuatan invensi dimaksud dapat disimpulkan bahwa bagian dari royalti dapat diberikan sepanjang masa manfaat ekonomi dari royalti masih mengalir. Hal ini mengingat pihak non PNS dan pihak ketiga mempunyai hak atas invensi dimaksud.

Dengan demikian, ada dua pendekatan yang perlu dipertimbangkan untuk diambil keputusan. Pendekatan yang pertama adalah Imbalan hanya berlaku kepada inventor dari institusi pemegang hak paten selama yang bersangkutan aktif sebagai pegawai. Pendekatan yang kedua adalah Imbalan berlaku selama umur manfaat Paten untuk inventor yang aktif atau sudah non aktif dari institusi.

Walaupun demikian, perlu pengaturan lebih lanjut apabila hak atas 
bagian dari pemanfaatan invensi ini dapat diteruskan selama manfaat ekonomi dari invensi dimaksud terus berjalan. Oleh karena itu, peraturan lain terlepas dari paket tersebut diatas perlu untuk dibentuk guna memayungi insentif dimaksud.

\subsection{Sistem Penggajian PNS}

Peneliti yang bekerja pada pemerintah selama ini digaji sesuai dengan ketentuan dalam PP tentang Gaji PNS, TNI, dan Polri. Selain itu, terdapat beberapa tunjangan tertentu terkait. Khusus untuk peneliti tunjangan fungsional peneliti telah ditetapkan dengan Perpres 100/2012. Bersamaan dengan itu terdapat pula sistem pembayaran remunerasi bagi kementerian/lembaga untuk mendukung reformasi birokrasi. Pengaturan terbaru yang terkait adalah dengan adanya UU 5 Tahun 2014 tentang Aparatur Sipil Negara.

Dengan konstruksi ini, kebijakan pemberian imbalan atas royalti perlu disesuaikan dengan kebijakan terkait dengan UU ASN ini dimana pada pasal 21 UU dimaksud disebutkan bahwa hak PNS adalah:

a. gaji, tunjangan, dan fasilitas;

b. cuti;

c. jaminan pensiun dan jaminan hari tua;

d. perlindungan; dan

e. pengembangan kompetensi.

Sedangkan, untuk Pegawai Pemerintah dengan Perjanjian Kontrak (PPPK) sendiri pada pasal 22 semua hak dimaksud diberikan dengan pengecualian untuk komponen fasilitas, dan jaminan pensiun dan jaminan hari tua.

Beberapa perhatian ditujukan pada gaji dan tunjangan yang telah diberikan terhadap profesi peneliti pemerintah dan upaya diarahkan bahwa imbalan yang diberikan harus dimasukkan dalam konstruksi yang sama dengan hak sebagaimana disebutkan dalam UU ASN dimaksud. Namun demikian perlu dipahami bahwa ada dua konsep berbeda antara apa yang disebutkan dalam konstruksi ASN diatas dengan imbalan yang dimaksudkan dalam kajian ini, yakni UU ASN pasal 21 dan pasal 22 berbicara mengenai hak pegawai sedangkan konstruksi imbalan adalah diskresi dari pemberi kerja untuk memotivasi pegawai. Dengan demikian, maka terdapat dua pilihan kebijakan dalam hal ini. Pertama, memasukkan aturan imbalan dalam konstruksi UU ASN mengenai hak pegawai dimaksud. Hal yang menjadi pendukung dari pilihan ini adalah kesesuaian dengan pengaturan mengenai pendapatan pegawai terutama jika dikaitkan dengan bonus kinerja sebagai bagian dari tunjangan kinerja, namun dilain pihak hal ini akan terkendala kedepan jika konstruksi yang dipakai adalah hak pegawai mengingat dengan konstruksi ini negara akan mendapat tuntutan dari para peneliti yang merasa ini adalah haknya.

Pilihan kedua adalah memasukkan aturan imbalan sebagai diskresi dari pemberi kerja. Konstruksi ini memang berada sedikit diluar konstruksi yang ada namun bisa terobosan kebijakan dengan tetap menempatkan kebijakan sebagai bagian dari diskresi pemerintah sebagai pemberi kerja. Pilihan ini dapat mengakomodasi ketentuan lain dari pemberian penghargaan kepada inventor yang dipekerjakan atau pernah dipekerjakan oleh pemerintah. 


\subsection{Hal-Hal lain yang menjadi} pertimbangan

Bagian ini mengidentifikasi pertimbangan lain yang dapat menjadi kekuatan sekaligus kelemahan dari kebijakan imbalan ini. Beberapa kekuatan sebagaimana secara implisit disampaikan pada bagian lain dapat dirangkum sebagai berikut:

1. Kebijakan ini dapat mendukung kemajuan ekonomi berbasis inovasi dalam negeri. Kemajuan ini secara mikro akan mendukung penambahan PNBP non SDA yang menjadi target pendapatan masa datang.

2. Kebijakan ini dapat menjadi salah satu alat pendukung dalam managemen sumber daya manusia, terutama untuk memelihara talenta tinggi dalam bidang penelitian dan pengembangan agar tetap berkarya untuk negeri. Selain itu, dari sisi managemen asset hal ini merupakan salah satu upaya untuk menghindari illegal lisensing atas kekayaan intelektual atau potential loss atas potensi terbentuknya intangible asset. Illegal lisensing merupakan tindakan melisensikan dibawah meja tanpa adanya kontribusi kepada negara. Sedangkan potential loss atas potensi terbentuknya intangible asset merupakan tindakan menjual potensi hasil penelitian sebelum hasil dari penelitian terwujud.

Namun dalam sisi lain, beberapa pertimbangan dapat dirangkum sebagai berikut:

1. Tidak semua penelitian akan menghasilkan paten, dan tidak semua paten laku dipasaran. Hal ini perlu menjadi bahan pertimbangan atas besaran imbalan agar diperoleh keseimbangan atas motivasi yang diterima orang di satu sisi dengan demotivasi yang mungkin dilakukan orang lain disisi lainnya. Bahkan dapat menjadi permasalahan besar jika paten yang dihasilkan bahkan digratiskan demi kepentingan yang lebih besar oleh negara.

2. Kebijakan ini dapat menjadi kontraproduktif dalam praktiknya, jika berlaku beberapa hal seperti berkembangnya sikap individualistik peneliti. Berkembangnya sistem HKI pada umumnya dikritisi oleh para akademisi saat ini sebagai penghambat kemajuan ilmu pengetahuan dan bergeser dari tujuan awal pembentukannya (Boldrin dan Levine, 2013).

Dari dua pertimbangan dimaksud kebijakan imbalan perlu diposisikan sebagai kebijakan tarik ulur bergantung pada situasi dan kondisi yang berlaku. Memperhatikan segala risiko atas potensi kehilangan bagi negara yang lebih besar maka kebijakan pemberian imbalan merupakan kebijakan yang layak direkomendasikan Untuk itu, rekomendasi terbaik adalah memberikan dengan besaran disesuaikan.

\section{KESIMPULAN DAN REKOMENDASI}

1. Kebijakan pemberian imbalan dari PNBP Royalti HKI mempunyai berbagai implikasi baik secara makro maupun mikro.

Salah satu implikasi dari sisi makro adalah adanya fakta bahwa adanya korelasi positif antara penelitian dan pertumbuhan ekonomi, bahkan beberapa negara maju (sebagai 
strategi untuk meningkatkan perekonomiannya) melakukan berbagai cara untuk menarik talenta terbaik dunia untuk masuk dan dipekerjakan dalam bidang riset dan pengembangan, sebuah trend yang dikenal dengan istilah Brain Drain. Kebijakan Bayh-Dole Act 1980 merupakan salah satu contoh upaya sebuah negara untuk memajukan penelitian serta nilai ekonomi dari hasil penelitian, dimana dalam salah satu kebijakannya inventor penghasil mendapatkan bagian 15\% dari hasil dimaksud.

Secara mikro kebijakan pemberian imbalan akan meningkatkan kapasitas pendapatan untuk pembiayaan penelitian yang dilakukan pemerintah. Bahkan walaupun dalam satu sisi meningkatkan pengeluaran, secara total general dengan semakin banyaknya penelitian yang dihasilkan kapasitas pendapatan akan semakin meningkat. Terlebih lagi bagi negara hal ini merupakan pendapatan negara masa depan yang tidak berbasiskan sumber daya alam sejalan dengan terus menurunnya sumber PNBP SDA. Dengan demikian, efek fiskal jika kebijakan ini dijalankan akan minim karena setiap tambahan pengeluaran selalu didahului oleh penerimaan negara.

Selain itu sebagai suatu langkah dalam managamen sumber daya manusia, kebijakan ini dapat menjadi langkah yang tepat untuk menjawab tantangan atas fenomena brain drain atas talenta terbaik Indonesia. Dari perspektif managemen asset, hal ini merupakan salah satu upaya untuk menghindari illegal lisensing atas kekayaan intelektual atau potential loss atas potensi terbentuknya intangible asset.

2. Imbalan atas PNBP Royalti HKI Paten dan PVT merupakan sesuatu yang berdasar hukum.

Dasar yang melandasi antara lain UU 14 Tahun 2001 tentang Paten, UU 29 Tahun 2000 tentang Perlindungan Varietas Tanaman , UU 18 Tahun 2002 tentang Sistem Nasional Penelitian dan Pengembangan IPTEK, serta PP 20 Tahun 2005 tentang Alih Teknologi Kekayaan Intelektual serta hasil kegiatan penelitian dan pengembangan oleh Perguruan Tinggi dan Lembaga Penelitian dan Pengembangan. UU 14 Tahun 2001 dan UU 29 Tahun 2000 memasukkan pasal mengenai imbalan terhadap penemunya (inventor/pemulia) beserta bentuk-bentuk imbalan. Sedangkan UU 18 Tahun 2002, dan PP 20 Tahun 2005 memasukkan tentang menjelaskan komersialisasi hasil pengetahuan serta batasan penggunaan komersialisasi untuk mendorong pengembangan ilmu pengetahuan selanjutnya (termasuk didalamnya memberikan insentif yang diperlukan untuk meningkatkan motivasi dan kemampuan invensi di lingkungannya).

Pengaturan tersebut diatas, sepanjang tidak dimaknai sebagai penggunaan langsung, tidak bertentangan dengan pengaturan PNBP.

3. Konsep Imbalan atas PNBP Royalti HKI agak sedikit berbeda Hak PNS/PPPK dalam UU ASN.

Pasal 21 dan Pasal 22 UU 5 Tahun 2014 tentang ASN menyebutkan hak yang 
diterima oleh PNS/PPPK dalam bentuk Gaji maupun Tunjangan, dilain pihak imbalan merupakan diskresi dari pemberi kerja terhadap pegawai yang dipekerjakan. Imbalan dibuat dalam kerangka bukan hak namun merupakan sebuah penghargaan dari pemberi kerja kepada pegawainya yang berprestasi. Penerima imbalan juga tidak terbatas pada PNS sebagai peneliti, namun pada inventor yang namanya disebutkan dalam dokumen paten/PVT.

Saat ini sedang berlangsung proses penyusunan draft RPP turunan dari UU ASN yang akan memasukkan pendapatan seperti diatas dalam payung tunjangan kinerja dengan subklasifikasi "bonus kinerja" dimana hal ini dapat menjadi solusi untuk inventor berstatus PNS namun belum pada nonPNSnya. Selain itu, sebagaimana dengan konstruksi UU ASN maka tidak semua ketentuan dalam sistem HKI dianut, misalnya peroleh imbalan hanya terbatas selama masa aktif kepegawaian bukan pada selama masa aktif kontribusi ekonomi suatu paten.

Terakhir, dasar pemikiran imbalan atas royalti ini adalah memberikan penghargaan atas upaya merealisasikan ide yang dituangkan dalam sebuah invensi bukan sematamata memberikan bagian atas penerimaan sebagai akibat dari kewenangan pemerintah sebagai regulator. Dengan demikian konstruksi yang dipakai dalam imbalan adalah kerelaan dari pemberi kerja (pemerintah) terhadap pegawainya atas kontribusi bagi organisasi.
4. PMK Imbalan atas PNBP royalti merupakan solusi awal sebagaimana dimaksudkan dalam Surat DJA Nomor S-1765/AG/2012 tanggal 09 Juli 2012.

Beberapa Kementerian/Lembaga penghasil PNBP Royalti HKI telah melakukan penyelesaian salah satu pengaturan yang disampaikan dalam surat dimaksud, sebagai contoh Kementerian PU dengan PP tarif dan KMK persetujuan penggunaan. Saat ini yang masih belum terdapat pengaturan adalah mengenai besaran atas imbalan dimaksud. PMK Imbalan yang telah disusun dapat menjadi solusi awal atas kekosongan peraturan sebagaimana dimaksud dalam surat tersebut diatas sampai dengan ketentuan lebih lanjut sebagai bagian dari UU ASN diterbitkan.

\section{DAFTAR PUSTAKA}

II. Experience of The US Government In Managing The Intellectual Property Right of Government Financed Programs. (2003). (). Beijing: Development Research Center of the State Council of the People's Republic of China. Retrieved from http://search.proquest.com/docview 212039059? accountid=37509.

Boldrin, M. dan Levine, David K. (2013), The Case Against Patents, Journal of Economic Perspectives, Volume 27, 1: 3-22.

Edi, R.Y. dan Subiyanto, B. (2014), Analisis Kasus Terhambatnya Pemberian Royalti kepada Inventor atas Hasil Alih Teknologi Kegiatan Litbang, 
http://www.opi.lipi.go.id/data/1228 964432/data/130867103213197979 97. makalah.pdf diakses tanggal 18 Agustus 2014.

Hassett, Kevin A. (2008). "Investment". In David R. Henderson (ed.). Concise Encyclopedia of Economics (2nd ed.). Indianapolis: Library of Economics and Liberty. ISBN 978-0865976658. OCLC 237794267.

Kerr, William (2013). High-Skilled Immigration, Domestic Innovation, dan Global Exchange. National Bureau of Economic Research Reporter, 4: 13-16.

Sattar, A., \& Mahmood, T. (2011). Intellectual Property Rights And Economic Growth: Evidences From High, Middle And Low Income Countries. Pakistan Economic and Social Review, 49(2), 163-186. Retrieved from http://search.proquest.com/docview $\angle 1017694020$ ?accountid=37509.

Saul Lach dan Mark Schankerman (2004) "Royalty Sharing and Technology Licensing in Universities," Journal of the European Economic Association, MIT Press, vol. 2(2-3), pages 252-264, 04/05.

Wong, R. H., Shulman, A., \& Wollin, D. (2002). The Paradox of Commercialising Public Sector Intellectual Property. Singapore Management Review, 24(3), 89-99.
Retrieved

from

http://search.proquest.com/docview /226852151 ?accountid=37509.

Peraturan Perundang-undangan:

- UU 20 Tahun 1997 tentang Penerimaan Negara Bukan Pajak;

- UU 14 Tahun 2001 tentang Paten, pasal 12 ayat (3);

- UU 18 Tahun 2002 tentang Sistem Nasional Penelitian dan Pengembangan IPTEK;

- UU 19 Tahun 2002 tentang Hak Cipta;

- UU 17 Tahun 2003 tentang Keuangan Negara;

- UU 1 Tahun 2004 tentang Perbendaharaan Negara;

- UU 29 Tahun 2009 tentang Perlindungan Varietas Tanaman;

- PP 73 Tahun 1999 tentang Tata Cara Penggunaan PNBP;

- PP 20 Tahun 2005 tentang Alih Teknologi Kekayaan Intelektual serta hasil kegiatan penelitian dan pengembangan oleh Perguruan Tinggi dan Lembaga Penelitian dan Pengembangan;

- PP 23 Tahun 2005 tentang Pengelolaan Keuangan Badan Layanan Umum;

- PP 90 Tahun 2010 tentang Penyusunan Rencana Kerja dan Anggaran Kementerian Negara/Lembaga; 